\title{
Compatibility of Sealing Materials with Biofuels and Biodiesel Heating Oil Blends at Different Temperatures
}

\section{Margit Weltschev}

Federal Institute for Materials Research and Testing, Berlin, 12205, Germany

\section{Abstract}

Biofuels including ethanol and biodiesel (fatty acid methyl ester, FAME) represent an important renewable fuel alternative to petroleum-derived transport fuels. Increasing biofuels use would bring some benefits, such as a reduction in oil demands and greenhouse gas emissions, and an improvement in air quality. Materials compatibility is a major concern whenever the fuel composition is changed in a fuel system.

The objective of this research was to determine the resistance of frequently used sealing materials such as CR (chloroprene rubber), CSM (chlorosulfonated polyethylene), EPDM (ethylene-propylenediene rubber), FKM (fluorocarbon ruber), FVMQ (methyl-fluorosilicone rubber), IIR (butyl rubber), NBR (acrylonitrile-butadiene rubber), PA (polyamides), PUR (polyester urethane rubber) and VMQ (methyl-vinyl-silicone rubber), in heating oil with admixtures of biogenic sources such as E10 (fuel with max. 10\% ethanol), E85 (fuel with $85 \%$ ethanol), non-aged and aged biodiesel, diesel fuel with $5 \%$ biodiesel, non-aged and aged $\mathrm{B} 10$ (heating oil with $10 \%$ biodiesel) at $20^{\circ} \mathrm{C}, 40^{\circ} \mathrm{C}$ and $70^{\circ} \mathrm{C}$. Mass, tensile strength and breaking elongation of the test specimens were determined before and after the exposure for 84 days in the fuels. The visual examination of some elastomer test specimens clearly showed the great volume increase until break or partial dissolution. Shore hardness A and D (for PA) were determined before and after exposure of the test specimens in the biofuels for 42 days.

There is not determined a threshold for the reduction in tensile properties and Shore hardness in the international standards. Therefore, a threshold of $15 \%$ was set for the evaluation of the compatibility. The sealing materials CR, CSM, EPDM, IIR and NBR were generally not resistant to biodiesel and B10. In summary, it can be therefore stated that the chemical resistance of the fluoropolymers FKM and FVMQ in fuels and biofuels is the best one.

\section{Introduction}

Biofuels including ethanol and biodiesel, FAME (fatty acid methyl ester), represent a renewable fuel alternative to petroleum-derived transport fuels. Increasing biofuel use would bring some benefits, such as a reduction in oil demand and greenhouse gas emissions, and an improvement in air quality. The relevance of biofuel production strongly depends on the respective potential in different countries, i.e. the availability of land or the usability of residues and by-products of important agricultural products. Furthermore, there is a significant technical potential for further development of biofuels as a renewable energy source [1].

Ethanol has become one of the main fuel components as it complies with environmental regulations. It is produced from carbohydrates such as sugar cane, sugar beet and corn. Ethanol-gasoline mixtures are commonly used in vehicles designed to run on gasoline thus the modification of some vehicle components is required as properties of the mixture are different from those of gasoline [2].

Biodiesel is manufactured from oilseeds, predominantly rapeseed, oil palm and soy. Differences between diesel and biodiesel are due to their different chemical nature. Diesel is composed of hundreds of compounds which boil at different temperatures, while biodiesel contains a few compounds, primarily the $\mathrm{C}_{16}-\mathrm{C}_{18}$ carbon chain, depending on the vegetable oil $[3,4]$.

Changes in fuel composition and the introduction of alternative fuels often create problems of corrosion and degradation in materials.

\section{Publication History:}

Received: January 19, 2019

Accepted: April 15, 2019

Published: April 17, 2019

\section{Keywords:}

Compatibility, Change in mass, Change in tensile properties, Change in Shore hardness, E10, E85, Fatty acid methyl ester (FAME), Heating oil with $10 \%$ Biodiesel (B10) use of ethanol-blended fuels, which is attributable to the absorption of oxygenated hydrocarbons that mainly cause swelling. The amount of swelling depends on the nature of the solvent and the polymer. Degradation processes are irreversible, producing changes in the elastomer because of the loss of its chemical structure. Besides the tendency of elastomers to swell, contact with ethanol may also alter the tensile strength and breaking elongation, causing weakening, cracking, leakage and brittle behavior [5].

The polarity of biodiesel increases its solvency and facilitates permeation and extraction. Solvation, swelling and/or extraction lead to changes in the physical properties. Extraction alters the fuel chemistry. These chemical changes could also accelerate the degradation (hydrolysis and oxidation) of the polymeric material with the loss of additives and stabilizers [6,7].

The aim of this work was to determine the physical and chemical behavior of different frequently used sealing materials (CR, CSM,

"Corresponding Author: Dr. Margit Weltschev, Federal Institute for Materials Research and Testing, Berlin, Germany, Tel: 004930 81043959; E-mail: margit.weltschev@bam.de

Citation: Weltschev M (2019) Compatibility of Sealing Materials with Biofuels and Biodiesel Heating Oil Blends at Different Temperatures. Int J Earth Environ Sci 4 : 165. doi: https://doi.org/10.15344/2456-351X/2019/165

Copyright: (C) 2019 Weltschev. This is an open-access article distributed under the terms of the Creative Commons Attribution License, which permits unrestricted use, distribution, and reproduction in any medium, provided the original author and source are credited. 
Citation: Weltschev M (2019) Compatibility of Sealing Materials with Biofuels and Biodiesel Heating Oil Blends at Different Temperatures. Int J Earth Environ Sci 4: 165. doi: https://doi.org/10.15344/2456-351X/2019/165

Page 2 of 9

EPDM, FKM, FVMQ, IIR, NBR, PA, PUR and VMQ) in biofuels such as E10 (fuel with max. 10\% ethanol), E85 (fuel with $85 \%$ ethanol), non-aged and aged biodiesel, diesel fuel with $5 \%$ biodiesel, nonaged and aged $\mathrm{B} 10$ (heating oil with $10 \%$ biodiesel) at $20^{\circ} \mathrm{C}, 40^{\circ} \mathrm{C}$ and $70^{\circ} \mathrm{C}$. First results of the exposure tests at $20^{\circ} \mathrm{C}, 40^{\circ} \mathrm{C}$ and $70^{\circ} \mathrm{C}$ were published in papers for CORROSION 2014, CORROSION 2015, CORROSION 2016, and CORROSION 2017 [8-11].

\section{Materials and Method}

\section{Preparation of test specimens}

Vulcanized rubber plates of CR, CSM, EPDM, FKM, FVMQ, IIR, NBR, PA, PUR and VMQ were used for the exposure tests. At least five test specimens of each polymer were cut out of the plates with the following dimensions according to DIN 53504 [12], Figure 1.

Total length: $110 \mathrm{~mm}$

Breadth at the end: $12.5 \mathrm{~mm}$

Length of the narrow parallel part: $25 \mathrm{~mm}$

Breadth of the narrow parallel part: $4 \mathrm{~mm}$

\section{Exposure tests in fuels}

Five tensile test specimens of each sealing material were exposed to E10, E85, non-aged and aged biodiesel, diesel fuel with 5\% biodiesel, non-aged and aged $\mathrm{B} 10$ at $20^{\circ} \mathrm{C}, 40^{\circ} \mathrm{C}$ and $70^{\circ} \mathrm{C}$ for 84 days in a specimen jar (diameter: $100 \mathrm{~mm}$, height: $200 \mathrm{~mm}$ ) with a sufficiently tight-fitting lid according to ISO 1817 [13]. The biodiesel was produced from rapeseed. The test specimens were fully immersed in the biofuels, Figure 1. Three circular test specimens of each sealing material for the determination of the Shore hardness were exposed for 42 days to the fuels at $20^{\circ} \mathrm{C}, 40^{\circ} \mathrm{C}$ and $70^{\circ} \mathrm{C}$.

\section{Determination of change in mass and visual detection}

The tensile test and the Shore hardness specimens were weighed before and after exposure to the biofuels at the standard laboratory temperature of $23^{\circ} \mathrm{C}$ and the standard laboratory humidity of $50 \pm$ $10 \%$. After exposure, the test specimens were inspected visually to detect damage such as greater swelling and volume change, as shown in Figure 1.

\section{Determination of tensile properties}

The tensile properties (tensile strength and breaking elongation) were determined according to DIN 53504 before and immediately after exposure at the standard laboratory temperature of $23^{\circ} \mathrm{C}$ and the standard laboratory humidity of $50 \pm 10 \%$ [12]

\section{Determination of shore hardness A and D}

The Shore Hardness A and D (for polyamide) was determined before and after exposure to the biofuels according to DIN 53505 at the standard laboratory temperature of $23^{\circ} \mathrm{C}$ and the standard laboratory humidity of $50 \pm 10 \%$ [14].

\section{Results and Discussion}

\section{Change in mass, tensile properties and Shore hardness in E10}

The immersion tests of elastomers in E10 and E85 at $60^{\circ} \mathrm{C}$ for 20 hours performed by Kass et al. led to the conclusion that the maximum swelling occurred at a content of $17-25 \%$ in the fuel for the fluorocarbon specimens. Fluorosilicone rubber achieved maximum swelling at $10 \%$ ethanol. The tests showed that NBR test specimens were less soluble in gasoline blends containing high levels of ethanol such as E85. Higher swelling was observed for gasoline blends with $10-17 \%$ ethanol [15].

The results of the present work confirmed the swelling of fluorocarbon specimens in E10 and the deterioration of NBR specimens at $70^{\circ} \mathrm{C}$ as shown in Figure 2. The measured weight gain of the test specimens caused by swelling was in the range of $2 \%(\mathrm{PA})$ to $83 \%$ (VMQ) at $20^{\circ} \mathrm{C}$, of $7 \%(\mathrm{PA})$ to $88 \%$ (VMQ) at $40^{\circ} \mathrm{C}$ and of $2 \%$ (IIR) to $103 \%(\mathrm{VMQ})$ at $70^{\circ} \mathrm{C}$. The lowest weight gain was measured for FKM, FVMQ and PA. A deterioration of NBR and CR test specimens was observed at $70^{\circ} \mathrm{C}$.

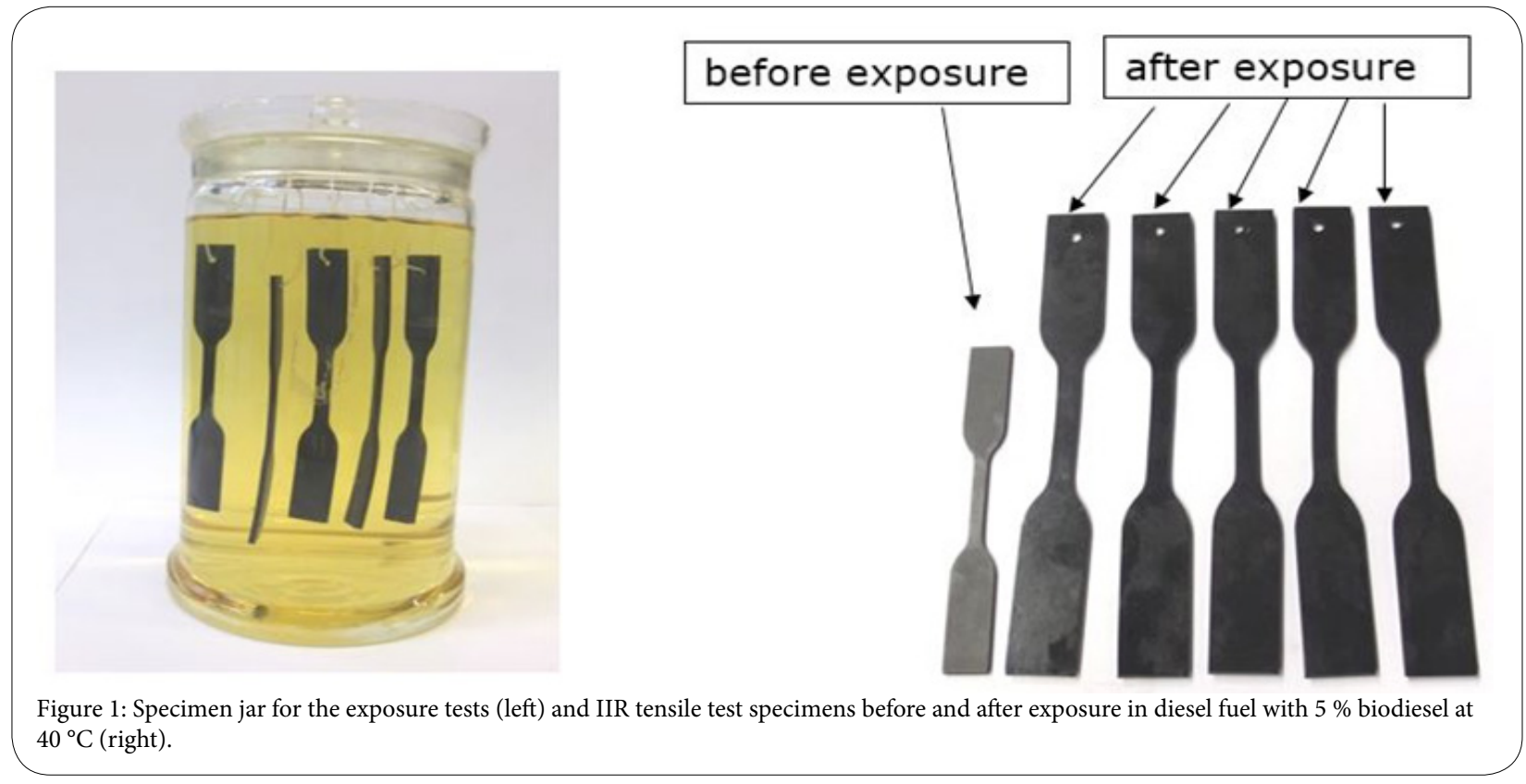


Citation: Weltschev M (2019) Compatibility of Sealing Materials with Biofuels and Biodiesel Heating Oil Blends at Different Temperatures. Int J Earth Environ Sci 4: 165. doi: https://doi.org/10.15344/2456-351X/2019/165

Swelling influenced the tensile properties. Loss in tensile strength and breaking elongation was lower at $20^{\circ} \mathrm{C}$ and $40^{\circ} \mathrm{C}$ than at $70^{\circ} \mathrm{C}$, as shown in Figure 3. Tensile strength decreased by 6\% (VMQ) to $69 \%(\mathrm{CR})$ at $20^{\circ} \mathrm{C}$, by $8 \%(\mathrm{VMQ})$ to $100 \%(\mathrm{CR})$ at $40^{\circ} \mathrm{C}$ and by $16 \%$ (VMQ) to $100 \%$ (NBR, CR) at $70^{\circ} \mathrm{C}$. Breaking elongation decreased by $1 \% \mathrm{EPDM}$ to $17 \%(\mathrm{CR})$ at $20^{\circ} \mathrm{C}$, by $1 \%(\mathrm{EPDM})$ to $100 \%(\mathrm{CR})$ at $40^{\circ} \mathrm{C}$ and by $15 \%(\mathrm{EPDM})$ to $100 \%(\mathrm{CR}, \mathrm{NBR}, \mathrm{PA})$ at $70^{\circ} \mathrm{C}$. The lowest decrease in tensile properties was determined for $\mathrm{FKM}$, EPDM, VMQ and IIR, and the highest for NBR, CSM and CR at the three test temperatures. There is not determined a threshold for the reduction in tensile properties and Shore hardness in the international standards. Therefore, a threshold of $15 \%$ was set for the evaluation of the compatibility. Based on this threshold of $15 \%$ FKM, FMVQ, CSM, EPDM, NBR, VMQ and PA were evaluated as resistant in $\mathrm{E} 10$ at $20^{\circ} \mathrm{C}$, FKM, FVMQ, EPDM and PA at $40{ }^{\circ} \mathrm{C}$, and none of the materials at $70^{\circ} \mathrm{C}$.

Swelling influenced the shore hardness of the test specimens too. Loss in Shore hardness increased with temperature rise to $70^{\circ} \mathrm{C}$, as shown in Figure 4. Shore hardness A decreased by 3\% (CR) to $36 \%$ (IIR) at $20^{\circ} \mathrm{C}$, by $12 \%$ (PUR) to $59 \%$ (IIR) at $40^{\circ} \mathrm{C}$ and by $23 \%$ (VMQ) to $100 \%$ (NBR, CR, CSM, IIR) at $70^{\circ} \mathrm{C}$. For PA was determined a decrease of Shore hardness $\mathrm{D}$ by $15 \%$ at $20^{\circ} \mathrm{C}$, by $11 \%$ at $40^{\circ} \mathrm{C}$ and by $84 \%$ at $70^{\circ} \mathrm{C}$. Based on a threshold of $15 \%$ for the reduction in Shore hardness FKM, FMVQ, EPDM, NBR, PA and PUR were evaluated as resistant in $\mathrm{E} 10$ at $20^{\circ} \mathrm{C}, \mathrm{FKM}, \mathrm{FVMQ}, \mathrm{PA}$ and PUR at $40^{\circ} \mathrm{C}$, and none of the tested materials at $70^{\circ} \mathrm{C}$.

\section{Change in mass, tensile properties and Shore hardness in E85}

The weight gain and weight loss of the test specimens caused by swelling and separation of plasticizers in E85 were in the range of 6\% (NBR) to $9 \%(\mathrm{PA})$ at $20^{\circ} \mathrm{C}$, of $4 \%(\mathrm{EPDM})$ to $9 \%(\mathrm{PA})$ at $40^{\circ} \mathrm{C}$ and of $4 \%$ (CR) to $12 \%$ (NBR) at $70{ }^{\circ} \mathrm{C}$. However, the weight gain of the fluorinated elastomers FKM and FVMQ were, together with IIR, at the lower end of this range at all test temperatures. CR test specimens lost $5 \%$ of their original weight at $20^{\circ} \mathrm{C}$ and $40^{\circ} \mathrm{C}$, and $5 \%$ at $70^{\circ} \mathrm{C}$, while IIR test specimens lost $1 \%$ of their original weight at $40^{\circ} \mathrm{C}$ and $70^{\circ} \mathrm{C}$. The damage was attributed to peroxides which were formed by alcohol oxidizing into carboxylic acids. Weight gain and weight loss of the test specimens were lower at $20^{\circ} \mathrm{C}$ and $40^{\circ} \mathrm{C}$ than at $70^{\circ} \mathrm{C}$.

Beside the tendency of elastomers to swell, contact with $85 \%$ ethanol affected the tensile properties too. Figure 5 shows that tensile strength decreased by $0.1 \%$ (FVMQ) to $25 \%$ (CSM, CR) at $20^{\circ} \mathrm{C}$, by $9 \%$ (PA) to $52 \%$ (EPDM, CR) at $40{ }^{\circ} \mathrm{C}$ and by $22 \%$ (IIR) to $100 \%$ (PUR) at $70^{\circ} \mathrm{C}$. Breaking elongation decreased by $0.3 \%$ (CSM) to $39 \%(\mathrm{CR})$ at $20^{\circ} \mathrm{C}$, by $6 \%(\mathrm{VMQ})$ to $54 \%(\mathrm{NBR})$ at $40^{\circ} \mathrm{C}$ and by $17 \%$
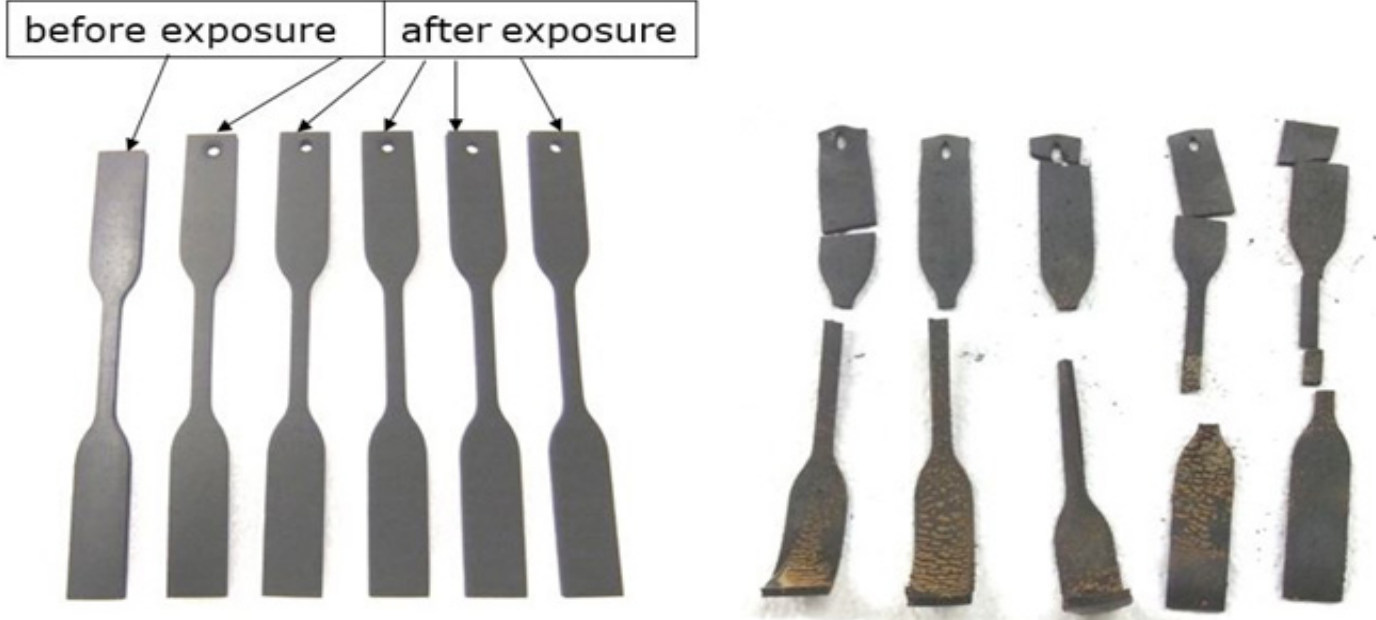

Figure 2: Specimens of FKM (left) and NBR (right) before and after exposure to E10 at $70^{\circ} \mathrm{C}$.
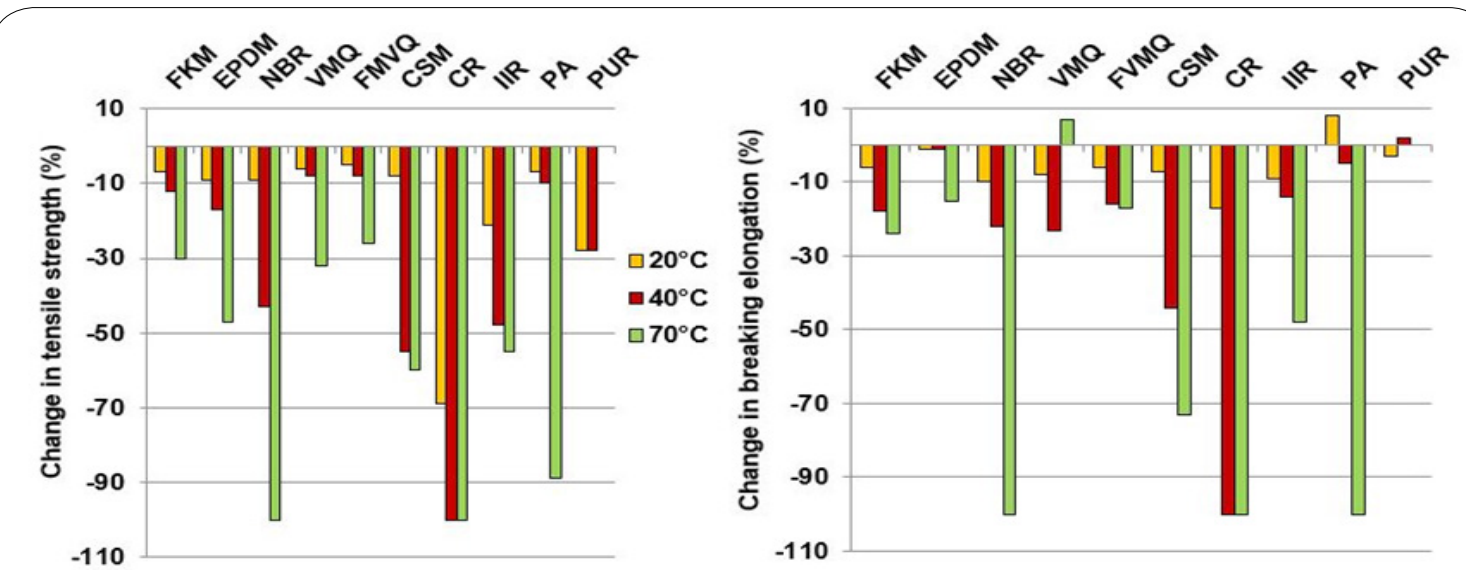

Figure 3: Change in tensile strength (left) and breaking elongation (right) of sealing materials after exposure to E10 for 84 days at $20^{\circ} \mathrm{C}, 40^{\circ} \mathrm{C}$ and $70^{\circ} \mathrm{C}$. 
Citation: Weltschev M (2019) Compatibility of Sealing Materials with Biofuels and Biodiesel Heating Oil Blends at Different Temperatures. Int J Earth Environ Sci 4: 165. doi: https://doi.org/10.15344/2456-351X/2019/165

Page 4 of 9

(FKM) to $100 \%(\mathrm{PA}, \mathrm{PUR})$ at $70^{\circ} \mathrm{C}$. Loss in tensile strength and breaking elongation was lower at $20^{\circ} \mathrm{C}$ and $40^{\circ} \mathrm{C}$ than at $70^{\circ} \mathrm{C}$
Swelling influenced the shore hardness of the test specimens too. Loss in Shore hardness increased with temperature rise to $70^{\circ} \mathrm{C}$, as shown in Figure 6. For Shore hardness A was determined a decrease
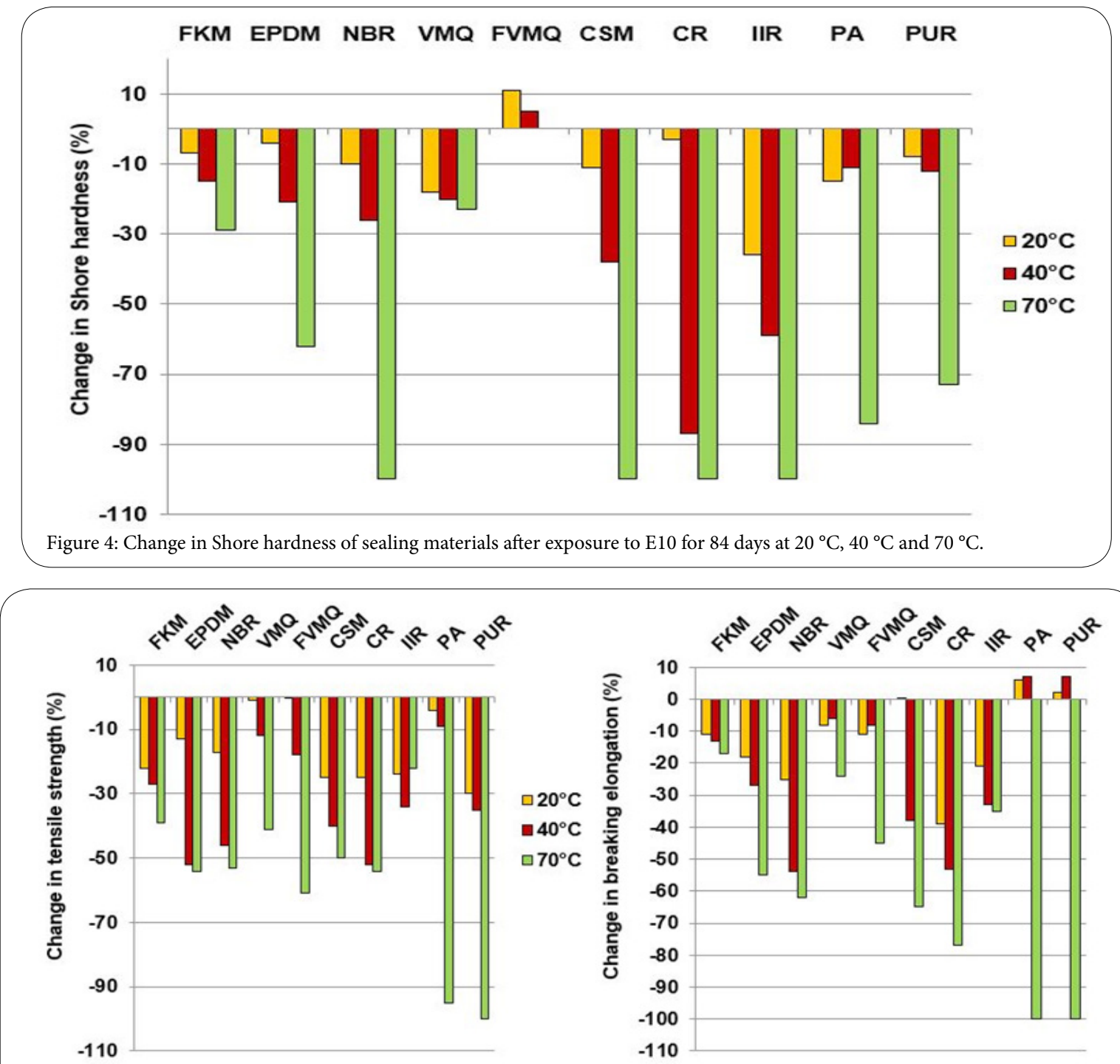

Figure 5: Change in tensile strength of sealing materials after exposure to E85 for 84 days at $20^{\circ} \mathrm{C}, 40^{\circ} \mathrm{C}$ and $70{ }^{\circ} \mathrm{C}$.

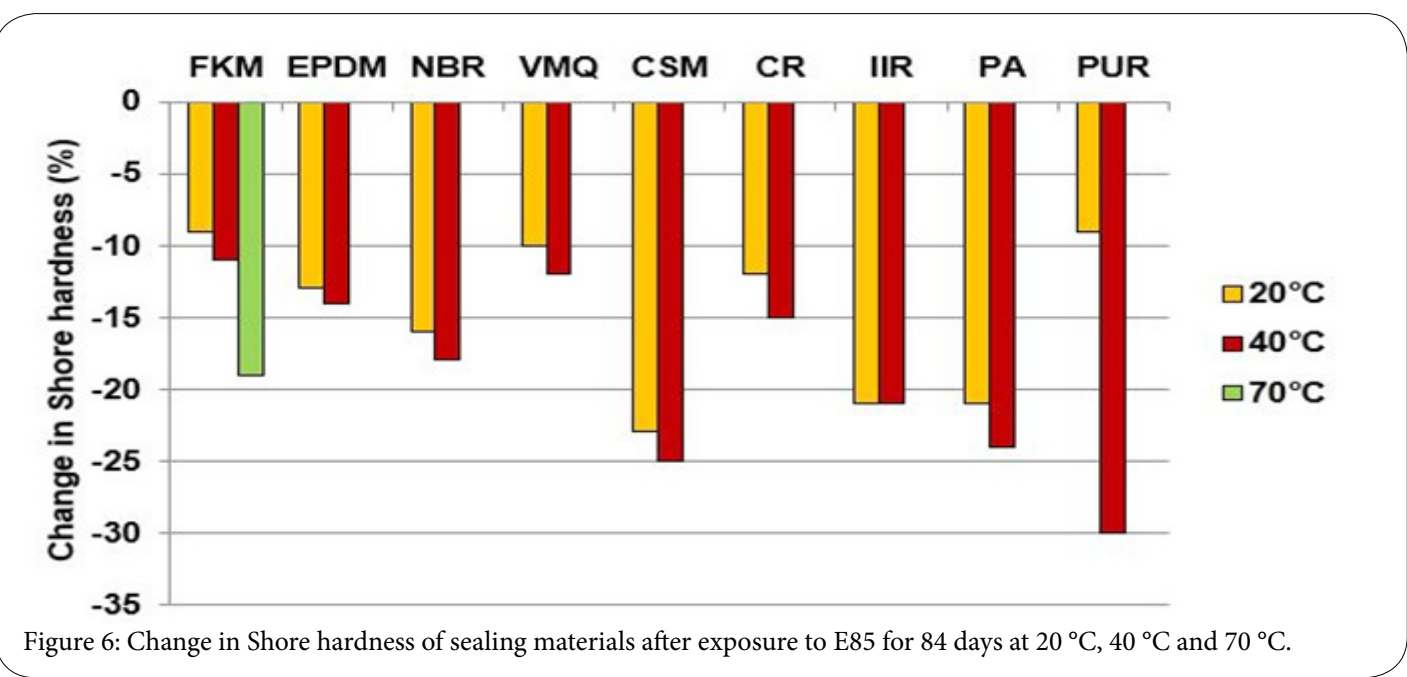


Citation: Weltschev M (2019) Compatibility of Sealing Materials with Biofuels and Biodiesel Heating Oil Blends at Different Temperatures. Int J Earth Environ Sci 4: 165. doi: https://doi.org/10.15344/2456-351X/2019/165

Page 5 of 9

by $9 \%$ (FKM, PUR) to $23 \%(\mathrm{CSM})$ at $20^{\circ} \mathrm{C}$, by $11 \%(\mathrm{FKM})$ to $30 \%$ (PUR) at $40^{\circ} \mathrm{C}$ and by $19 \%(\mathrm{FKM})$ at $70^{\circ} \mathrm{C}$. For PA was determined a decrease of Shore hardness D by $21 \%$ at $20^{\circ} \mathrm{C}$ and by $24 \%$ at $40^{\circ} \mathrm{C}$. Based on a threshold of $15 \%$ for the reduction in Shore hardness FKM, EPDM, VMQ, CR and PUR were evaluated as resistant in E85 at $20^{\circ} \mathrm{C}, \mathrm{FKM}, \mathrm{EPDM}, \mathrm{CR}$ and VMQ at $40^{\circ} \mathrm{C}$, and none of the tested materials at $70^{\circ} \mathrm{C}$.

Note: the Shore hardness was not determined for FVMQ in E85.

\section{Change in mass, tensile properties and Shore hardness in non-aged} and aged biodiesel

When exposed to biodiesel, elastomers are affected in two ways: firstly, by absorption of liquid by the elastomers and, secondly, by dissolution of soluble components of the elastomers in the liquid medium. Swelling is the result of the high absorption by elastomers in comparison to their dissolution in the fuel. Test specimens of CR, CSM, EPDM, IIR and NBR were damaged to a high degree by swelling. The reason is their polar nature when they are dissolved in the biodiesel with its polar ester group.

The weight gain of the elastomers varied between $0.3 \%$ (FKM) and $78 \%(\mathrm{CR})$ in non-aged biodiesel and between $0.4 \%$ (FKM) and 108\%
(EPDM) in 2-year aged biodiesel. Aging of the biodiesel increased the swelling and weight gain of the sealing materials.

The tensile strength and breaking elongation were affected to a high degree. The values decreased to a large extent in the case of EPDM $(100 \%)$, NBR $(100 \%)$ and CR $(100 \%)$ in 2-year aged biodiesel at $20^{\circ} \mathrm{C}$, $40^{\circ} \mathrm{C}$ and $70^{\circ} \mathrm{C}$. CSM lost $100 \%$ at $40^{\circ} \mathrm{C}$ and $70^{\circ} \mathrm{C}$, as shown in Figure 7 . CR, CSM, EPDM, IIR and NBR were not resistant at all in biodiesel, independently of the age and the temperature.

FKM showed, with a loss in tensile strength and breaking elongation less than $10 \%$, high compatibility with non-aged and 2-year aged biodiesel at $20^{\circ} \mathrm{C}$ and $40^{\circ} \mathrm{C}$, which was attributed to the absence of polarity. FKM lost $18 \%$ of its tensile strength and $11 \%$ of its breaking elongation in non-aged biodiesel at $70^{\circ} \mathrm{C}$. The reduction in tensile strength and breaking elongation was lower with $16 \%$ and $2 \%$ respectively in 2-year aged biodiesel at this temperature. Using a threshold of $15 \%$ in the reduction in tensile properties, FKM was evaluated as resistant in non-aged and 2-year aged biodiesel at all test temperatures.

The diagrams with changes in Shore hardness in Figure 8 show clearly that the elastomers CR, CSM, EPDM, IIR and NBR were not
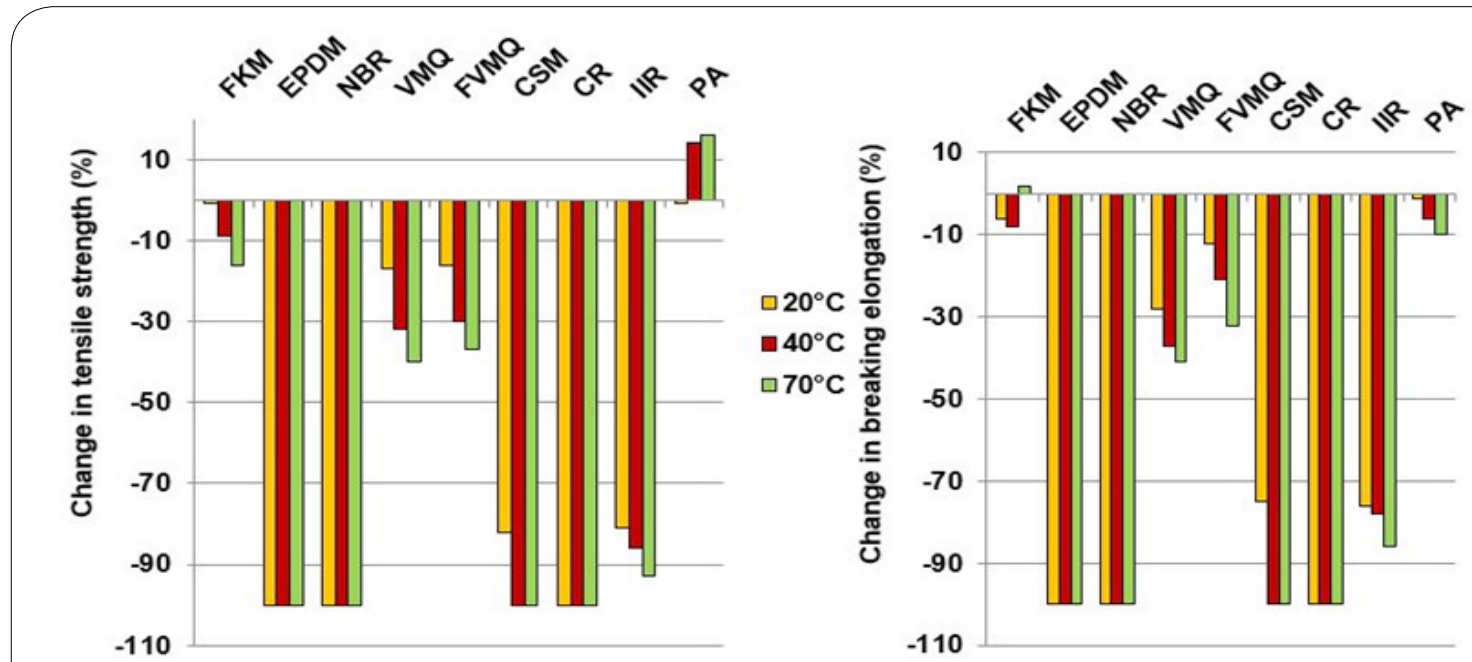

Figure 7: Change in tensile strength (left) and breaking elongation (right) of sealing materials after exposure to 2-year aged biodiesel for 84 days at $20^{\circ} \mathrm{C}, 40^{\circ} \mathrm{C}$ and $70^{\circ} \mathrm{C}$.
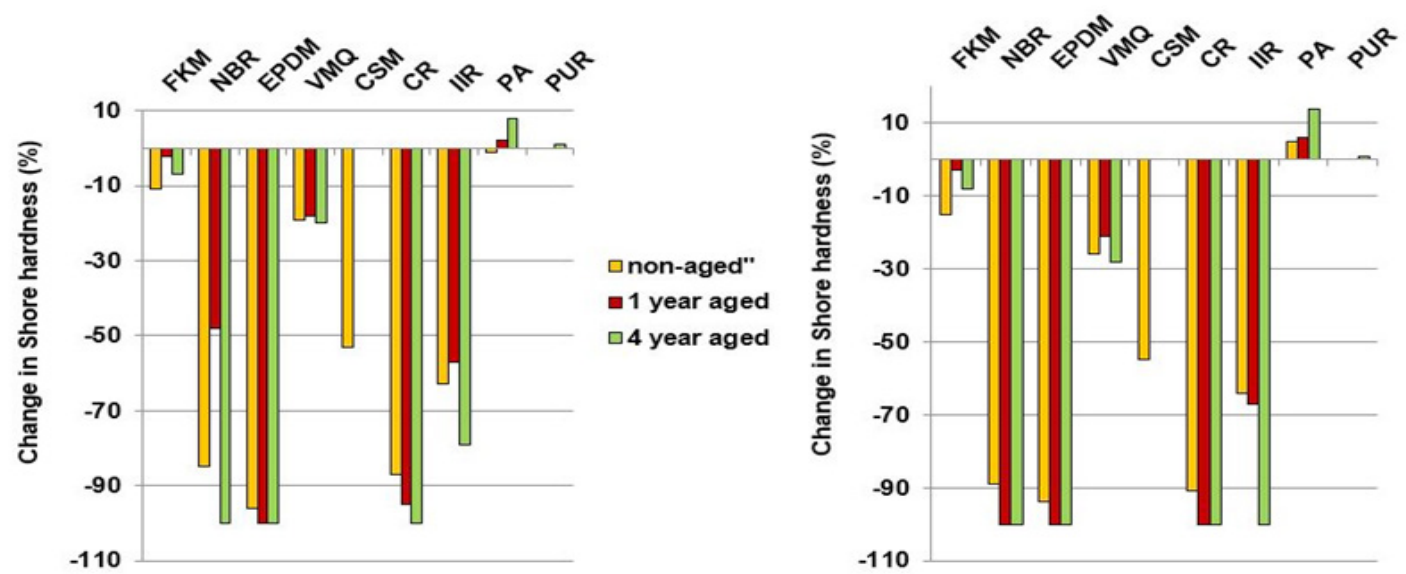

Figure 8: Change in Shore hardness of sealing materials after exposure to biodiesel of different ages at $20^{\circ} \mathrm{C}$ (left) and $40{ }^{\circ} \mathrm{C}$ (right). 
Citation: Weltschev M (2019) Compatibility of Sealing Materials with Biofuels and Biodiesel Heating Oil Blends at Different Temperatures. Int J Earth Environ Sci 4: 165. doi: https://doi.org/10.15344/2456-351X/2019/165

Page 6 of 9

resistant at all in biodiesel of all ages at $20^{\circ} \mathrm{C}$ und $40^{\circ} \mathrm{C}$. Whereas fluorocarbon rubber lost $2 \%$ of its Shore hardness at $20^{\circ} \mathrm{C}$ and $3 \%$ at $40^{\circ} \mathrm{C}$ in 1-year aged biodiesel, the Shore hardness was reduced by $7 \%$ at $20^{\circ} \mathrm{C}$ and by $8 \%$ at $40^{\circ} \mathrm{C}$ in 4 -year aged biodiesel.

For polyamide was determined an increase by $2 \%$ at $20^{\circ} \mathrm{C}$ and $6 \%$ at $40^{\circ} \mathrm{C}$ in 1-year aged biodiesel, and an increase by $8 \%$ at $20^{\circ} \mathrm{C}$ and by $14 \%$ at $40^{\circ} \mathrm{C}$ in 4 -year-aged biodiesel.

Change in mass, tensile properties and Shore hardness in diesel fuel

The weight gain of NBR test specimens caused by swelling in diesel fuel with max. $5 \%$ biodiesel at $20^{\circ} \mathrm{C}, 40^{\circ} \mathrm{C}$ and $70^{\circ} \mathrm{C}$ is shown in Figure 9 .

However, the weight gain of the fluorinated elastomer FKM were, together with PUR, at the lower end of this range at all test temperatures, as shown in Figure 10. IIR and NBR test specimens showed the highest weight gain with $184 \%$ (IIR) and $32 \%$ (NBR) at $20^{\circ} \mathrm{C}, 195 \%$ (IIR) and $129 \%\left(\mathrm{NBR}\right.$ ) at $40^{\circ} \mathrm{C}$, and $134 \%(\mathrm{NBR})$ at $70^{\circ} \mathrm{C}$, while PA test specimens lost $10 \%$ of their original weight at $20^{\circ} \mathrm{C}$ and $40^{\circ} \mathrm{C}$

Loss in Shore hardness increased with temperature rise to $70^{\circ} \mathrm{C}$, as shown in Figure 11. For Shore hardness A was determined a decrease by $1 \%$ (FKM, PUR) to $64 \%$ (CR) at $20^{\circ} \mathrm{C}$, by $1.5 \%$ (FKM, PUR) to $70 \%$ (CR) at $40^{\circ} \mathrm{C}$ and by $12 \%(\mathrm{FKM})$ to $95 \%$ (NBR) at $70^{\circ} \mathrm{C}$. For PA was determined an increase of Shore hardness $\mathrm{D}$ by $13 \%$ at $20^{\circ} \mathrm{C}$ and by $11 \%$ at $40^{\circ} \mathrm{C}$. Based on a threshold of $15 \%$ for the reduction in Shore hardness FKM, NBR, PA and PUR were evaluated as resistant in diesel fuel with max. $5 \%$ biodiesel at $20^{\circ} \mathrm{C}, \mathrm{FKM}, \mathrm{PA}$ and PUR at $40^{\circ} \mathrm{C}$, and only FKM at $70^{\circ} \mathrm{C}$.

In Figure 12 is shown the influence of max. biodiesel addition to diesel fuel on the change in Shore hardness A at $40^{\circ} \mathrm{C}$. The Shore hardness A of NBR test specimens was reduced after exposure to diesel fuel with max. $5 \%$ biodiesel by $18 \%$ more than in pure diesel fuel.
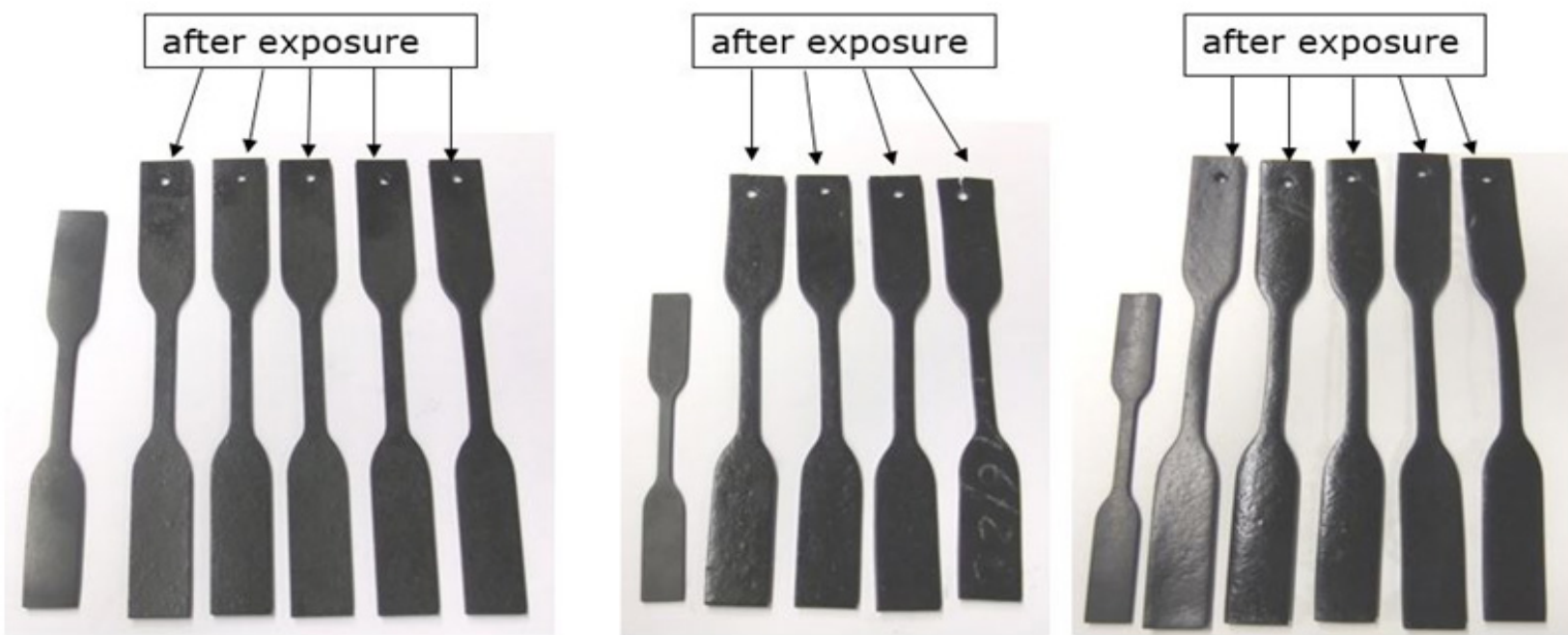

Figure 9: Specimens of NBR before and after exposure to diesel fuel with max. $5 \%$ biodiesel at $20^{\circ} \mathrm{C}$ (left), $40^{\circ} \mathrm{C}$ (center) and $70^{\circ} \mathrm{C}$ (right) for 84 days.

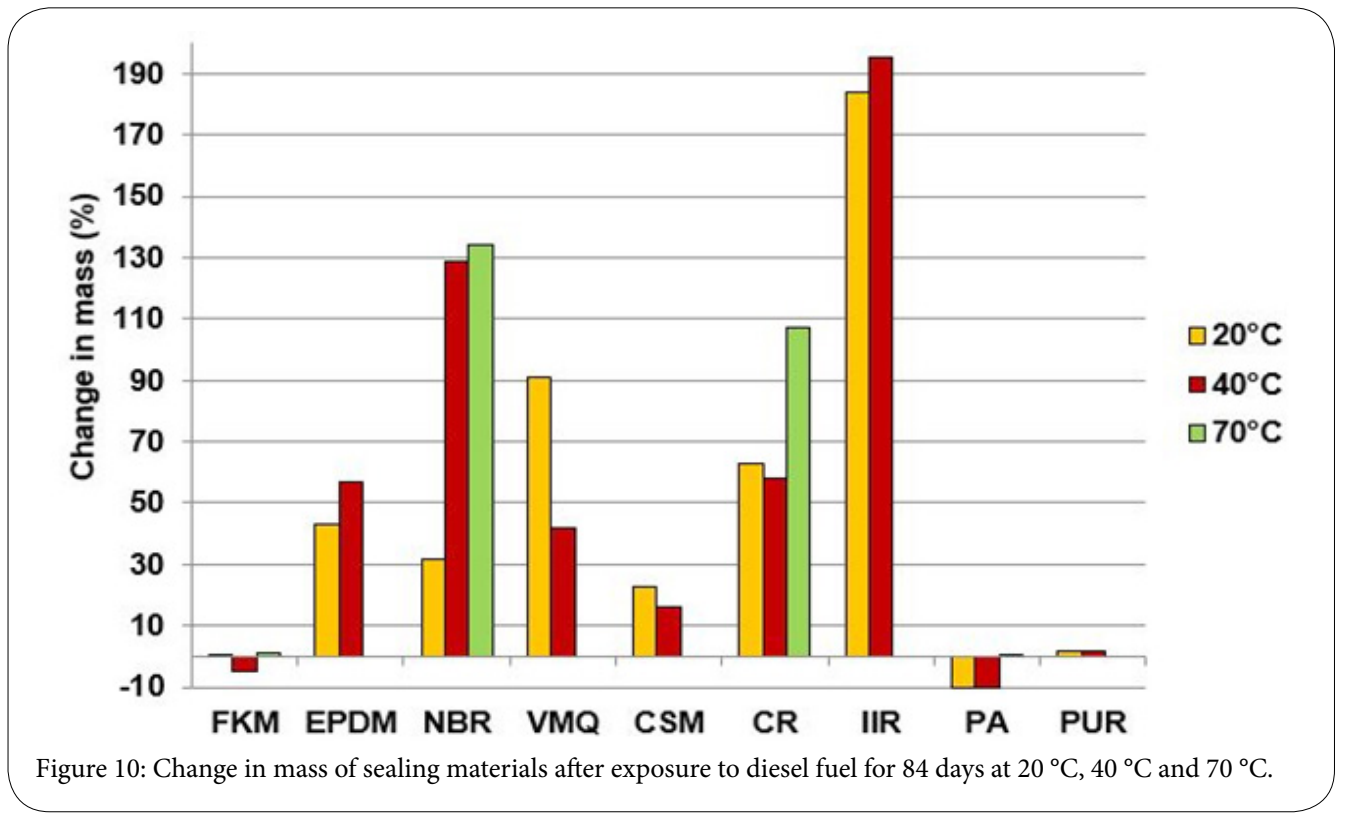


Citation: Weltschev M (2019) Compatibility of Sealing Materials with Biofuels and Biodiesel Heating Oil Blends at Different Temperatures. Int J Earth Environ Sci 4: 165. doi: https://doi.org/10.15344/2456-351X/2019/165

Page 7 of 9

Change in mass, tensile properties and Shore hardness in non-aged and aged $\mathrm{B} 10$

Test specimens of CSM, CR, EPDM, IIR and NBR were damaged to a high degree by swelling in both non-aged and aged B10, which consists of $10 \%$ biodiesel (FAME) produced from rapeseed. Figure 13 shows EPDM specimens after exposure to 1 -year aged $\mathrm{B} 10$ at $40^{\circ} \mathrm{C}$ and NBR specimens after exposure to 4 -year aged $\mathrm{B} 10$ at $70^{\circ} \mathrm{C}$. The highest weight at $20^{\circ} \mathrm{C}$ was determined for EPDM with $149 \%$ and for NBR with $102 \%$, and at $40^{\circ} \mathrm{C}$ for EPDM with $140 \%$ and for NBR with $184 \%$ in 4 -year aged B10. Weight gain was increased by increasing the temperature to $40^{\circ} \mathrm{C}$ and $70^{\circ} \mathrm{C}$. The highest weight gain was
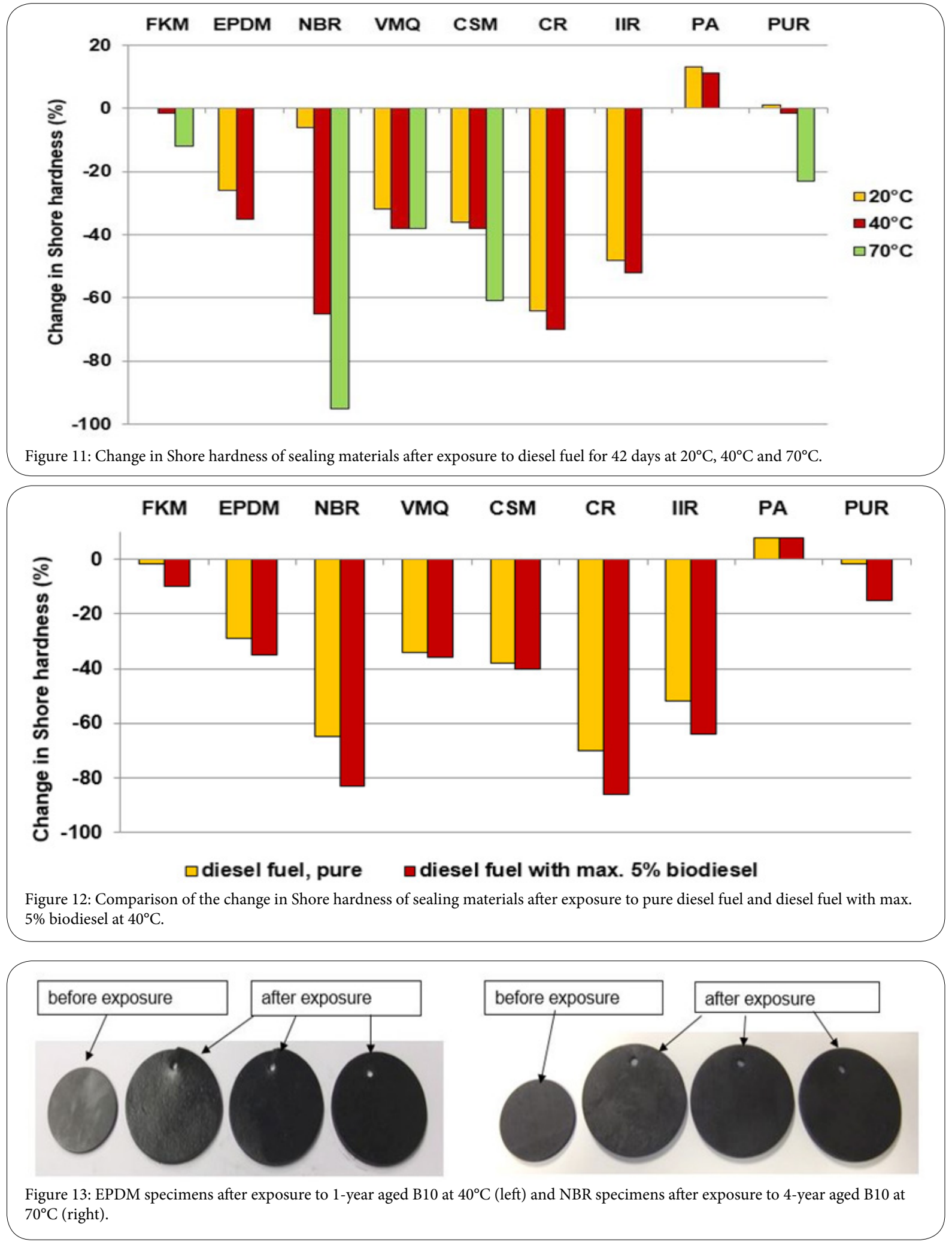
Citation: Weltschev M (2019) Compatibility of Sealing Materials with Biofuels and Biodiesel Heating Oil Blends at Different Temperatures. Int J Earth Environ Sci 4: 165. doi: https://doi.org/10.15344/2456-351X/2019/165

Page 8 of 9

measured for CR with 240\%, IIR with 192\%, CSM with 106\%, EPDM with $96 \%$ and VMQ with $54 \%$ in one-year aged $\mathrm{B} 10$ at $70^{\circ} \mathrm{C}$, while the elastomers containing fluorine FKM (1\%) and FVMQ (3\%) absorbed much less B10 and swelled less.

As shown in Figure 14, the tensile strength and breaking elongation were affected to a high degree by swelling of the test specimens. The values decreased to a large extent in the case of CSM (100\%), EPDM (100\%) and NBR (100\%) in 2-year aged $\mathrm{B} 10$ at $20^{\circ} \mathrm{C}, 40^{\circ} \mathrm{C}$ and $70^{\circ} \mathrm{C}$. CSM lost $100 \%$ at $40^{\circ} \mathrm{C}$ and $70^{\circ} \mathrm{C}$. CR, CSM, EPDM, IIR and NBR were not resistant at all in $\mathrm{B} 10$, independently of the age and the temperature.

Changes in Shore hardness confirmed that the elastomers CR, CSM, EPDM, IIR, NBR and VMQ were not resistant to heating oil with $10 \%$ biodiesel at all at $20^{\circ} \mathrm{C}, 40^{\circ} \mathrm{C}$ and $70^{\circ} \mathrm{C}$, regardless of the age of the heating oil. The Shore hardness of fluorocarbon rubber specimens was reduced with the higher age of heating oil with $10 \%$ biodiesel and higher temperature. Shore hardness was reduced by $1 \%$ in one-year aged heating oil, by $4 \%$ in two-year aged heating oil, by $6 \%$ in three-year aged heating oil and by $7 \%$ in four-year aged heating oil at $20^{\circ} \mathrm{C}$. The highest reduction in Shore hardness was measured with $12 \%$ in two-year aged heating oil, $13 \%$ in three-year aged heating oil and $18 \%$ in four-year aged heating oil at $70^{\circ} \mathrm{C}$

Figure 15 shows clearly the influence of $10 \%$ biodiesel on the reduction in Shore hardness of the sealing materials after exposure to standard heating oil and non-aged B10 for 42 days at $40^{\circ} \mathrm{C}$. The reduction in Shore hardness is higher in B10 compared with standard heating oil

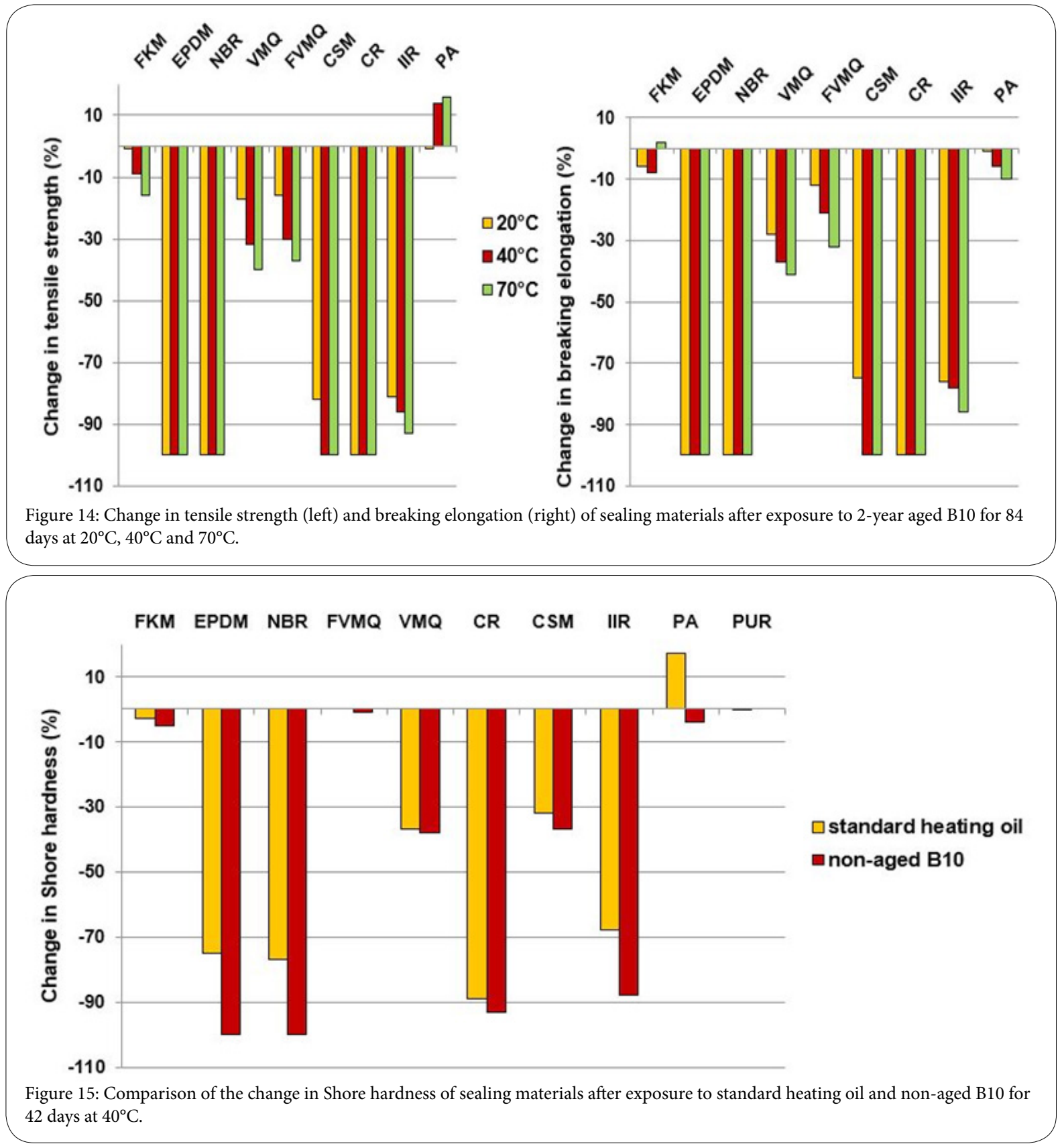


Citation: Weltschev M (2019) Compatibility of Sealing Materials with Biofuels and Biodiesel Heating Oil Blends at Different Temperatures. Int J Earth Environ Sci 4: 165. doi: https://doi.org/10.15344/2456-351X/2019/165

Page 9 of 9

\section{Conclusion}

Measurements of the variations in mass, tensile properties and Shore hardness after exposure of ten different sealing materials - CR, CSM, EPDM, FKM, FVMQ, IIR,NBR, PA, PUR and VMQ- to E10, E85, diesel fuel, non-aged and aged biodiesel and B10 showed clearly that FKM and FVMQ were the most resistant material in all tested fuels up to $70^{\circ} \mathrm{C}$. Damage to the materials was lower at $20^{\circ} \mathrm{C}$ and $40^{\circ} \mathrm{C}$ than at $70^{\circ} \mathrm{C}$.

There is not determined a threshold for the reduction in tensile properties and Shore hardness in the international standards. Therefore, a threshold of $15 \%$ was set for the evaluation of the compatibility.

Based on this threshold FKM, FMVQ, CSM, EPDM, NBR, PA and PUR were evaluated as resistant in $\mathrm{E} 10$ at $20^{\circ} \mathrm{C}, \mathrm{FKM}, \mathrm{FVMQ}, \mathrm{PA}$ and PUR $40^{\circ} \mathrm{C}$, and none of the tested materials at $70^{\circ} \mathrm{C}$.

E85 was less aggressive than biodiesel and B10. Using a threshold of $15 \%$ for the reduction in tensile properties the sealing materials FVMQ, VMQ and PA were evaluated as resistant in $\mathrm{E} 85$ at $20^{\circ} \mathrm{C}$ and $40^{\circ} \mathrm{C}$. None of the sealing materials were evaluated as resistant in E85 at $70^{\circ} \mathrm{C}$, and PA as well as PUR even started to decompose.

Biodiesel fuels are easily oxidized and contain acids and water. NBR, IIR, CR, CSM and EPDM were not resistant at all in biodiesel, independently of the age. FKM and PA showed high compatibility in biodiesel, which was attributed to the absence of polarity. The decrease in tensile properties and Shore hardness increased with the age and the temperature of the biodiesel, but the measured values were still lower than the defined threshold of $15 \%$.

FKM, PA and PUR were evaluated as resistant in diesel fuel with at least $5 \%$ biodiesel, only FKM was resistant up to $70^{\circ} \mathrm{C}$. CR, CSM, EPDM, IIR, NBR and VMQ were not resistant at all to diesel fuel at all test temperatures.

FKM and FVMQ absorbed much less non-aged and aged B10 and swelled less. CR, CSM, EPDM, IIR, NBR and VMQ were not resistant to $\mathrm{B} 10$ at all at $20^{\circ} \mathrm{C}, 40^{\circ} \mathrm{C}$ and $70^{\circ} \mathrm{C}$ as the decrease in the tensile properties was significantly over $50 \%$.

FVMQ and PA could be evaluated as resistant in non-aged and aged $\mathrm{B} 10$ at $20^{\circ} \mathrm{C}$ and $40^{\circ} \mathrm{C}$, whereas $\mathrm{FKM}$ was resistant up to $70^{\circ} \mathrm{C}$. The damaging impact of non-aged B10 was higher than that of 4-year aged B10.

\section{Competing Interests}

The author declare that there is no competing interests regarding the publication of this article.

\section{References}

1. Deng YY, Koper M, Haigh M, Dornburg V (2015) Country -level assessment of long-term global bioenergy potential. Biomass Bioenergy 74: 253-267.

2. Agarwal AK (2007) Biofuels (alcohols and biodiesel) applications as fuels for internal combustion engines. Progress in Energy and Combustion Science 33: $233-271$.

3. HaseebASMA, Masjuki HH, Ciang CT, Fazal MA (2010) Compatibility of elastomers in palm biodiesel. Renewable Energy 35: 2356-2361.
4. Knothe G (2010) Biodiesel and renewable diesel; A comparison. Progress in Energy and Combustion Science 36: 364-373.

5. Baena L, Jaramillo JA, Calderon JA (2012) Aggressiveness of a $20 \%$ bioethanol $80 \%$ gasoline mixture on autoparts: II Behavior of polymeric materials. Fuel 95: 312-319.

6. Alves SM, Mello VS, Medeiros JS (2013) Palm and soybean compatibility with fuel system elastomers. Tribology International 65: 74-80.

7. Haseeb ASMA, Fazal MA, Jahirul MI, Masjuki HH (2011) Compatibility of automotive materials in biodiesel: A review. Fuel: 90: 922-931.

8. Weltschev M, Werner J, Heming F (2014)Compatibility of elastomers with biofuels, Proceedings of CORROSION. Houston, TX, NACE.

9. Weltschev $M$, Heming F, Haufe M, Heyer M (2015) Compatibility of sealing materials with biofuels and biodiesel-heating oil blends. Proceedings of CORROSION. Houston, TX, NACE.

10. Weltschev $M$, Werner J, Heming F, Jochems F (2016) Impact of biocomponents in the fuel and heating oil on the compatibility of sealing materials. CORROSION. Houston, TX, NACE.

11. Weltschev M, Haufe M, Heyer M (2017) Compatibility Evaluations of Sealing Materials with Aged Biofuels. CORROSION. Houston TX NACE.

12. DIN Deutsches Institut für Normung e.V. (2017) DIN 53504 - Testing of rubber - determinations of tensile strength at break, tensile stress at yield, elongation at break and stress values in a tensile test.

13. ISO International Standard Organization (2015) ISO 1817 - Rubber vulcanized - Determination of the effect of liquids.

14. DIN Deutsches Institut für Normung e.V. (2000) DIN 53505 - Testing of rubber - Shore A and Shore D hardness test.

15. Kass M, Thiess T, Janke Ch, Pawel S, Chapin JT, et al. (2012) Compatibility of elastomers with test fuels of gasoline blended with ethanol. Sealing Technology 12: 7-12. 